was still present after $1 \mathrm{~h}$. Table 1 also reveals that the 1-h fits were significantly less severe, in terms of duration, than those occurring in the initial sessions $(t=2 \cdot 2$, $P<0.05$ ), and their production required significantly more shocks than the 2-h fits (Mann-Whitney $U=11$, $P<0.05$ ).

Clinical evidence of post-ictal resistance to fits is necessarily difficult to obtain, but a recent report describes an epileptic patient in whom self-induced seizures conferred a temporary freedom from spontaneous attacks ${ }^{4}$. The neurological state underlying a resistance of this kind could explain why a fit stops ${ }^{5}$, and why identical foci in different patients may or may not give rise to overt epilepsy ${ }^{6}$.

We thank tho Medical Research Council and Prof. R. W. Gilliatt for support and facilities.

\section{J. HerberG}

P. J. WATKINS

Experimental Psychology Laboratory, Institute of Nourology,

National Hospital for Nervous Diseases, Queen Square, London, W.C.1.

${ }^{1}$ Olds, J., and Olds, M. E., in Brain Mechanisms and Learning, edit. by Delafresnaye, J. F. (Blackwell, Oxford, 1961).

2 Miller, N. E. in Electrical Stimulatiom of the Brain, edit, by Sheer, D. F. (Texas Univ. Press, Austin, 1961)

${ }^{3}$ Herberg, L, J., J. Comp, Physiot. Psychol., 56, 679 (1963).

4 Symonds, C., Brain, 82, 10 (1959).

${ }^{8}$ Efron, R., Brain, 80, 251 (1957).

${ }^{6}$ Falconer, M. A., and Cavanagh, J. B., Brain, 82, 483 (1959).

\section{PHARMACOLOGY}

\section{Effect of Promethazine Hydrochloride on Hand-Eye Co-ordination}

THE potential danger to driving and other tasks of barbiturate and antihistamine drugs has been emphasized ${ }^{1}$. While the former have been widely investigated, the central effects of antihistamine drugs are not fully realized, although they are easily accessible to the genoral public.

An investigation has been carried out into the effect of promethazine hydrochloride ('Phenergan') on visuo-motor co-ordination.

The apparatus consisted of a rotating drum (1 rotation/ $53 \mathrm{sec}$ ) covered with an insulating layer in which 400 holes had been cut. On tho 'disk-dotting' principle, and using a steering wheol of $18 \mathrm{~cm}$ diameter, the subject followed the irregular course of the holes, so establishing olectrical contact and recording the score on a digital computer.

Four healthy male students, aged between 21 and 23 years, took part in a double-blind cross-over experiment in which promethazine hydrochloride $(50 \mathrm{mg})$ was com parod with a placebo at 2 -weekly intervals. Each subject was fully farniliarized with the technique in order to minimize loarning effects. Thoy abstained from stimulants and cigarettes during the experiment.

Before, and at 1,2 and $3 \mathrm{~h}$ aftor administration of the drug or placebo, measurements were recorded over eight rotations of the drum, with an interval of $1 \mathrm{~min}$ betwoen each rotation.

The mean values of the highest score of each determina tion at any one time in the four subjects wore obtained and the results are shown in Fig. 1. Promethazine hydrochloride produced a significant fall in score $(P<0.05)$ compared with the placebo at $3 \mathrm{~h}$, but no significant difference was seen at 1 and $2 \mathrm{~h}$.

The moan of each eight doterminations was cornpared with the highest value of the same for each occasion in sach subject. A highly significant corrolation was found between them $(r=0.882, P<0.001)$.

Although antihistamine drugs are known to produce varying dogrees of central nervous depression, fow controlled trials have been carried out on specific functions.
Impairment of visual flicker discrimination by diphenhydramine ( $25 \mathrm{mg}$ ) was demonstrated by Roback, Krasno and $\mathrm{Ivy}^{2}$, and Payne ${ }^{3}$ found that meclozine (50 mg) significantly impaired memory for verbal material. On the other hand, Colquhoun ${ }^{4}$ was unable to detect significant impairment of vigilanco or short-term memory after administration of meclozine (50 $\mathrm{mg})$ although it was marked if the drug was given together with $32 \mathrm{~g}$ ethyl alcohol.

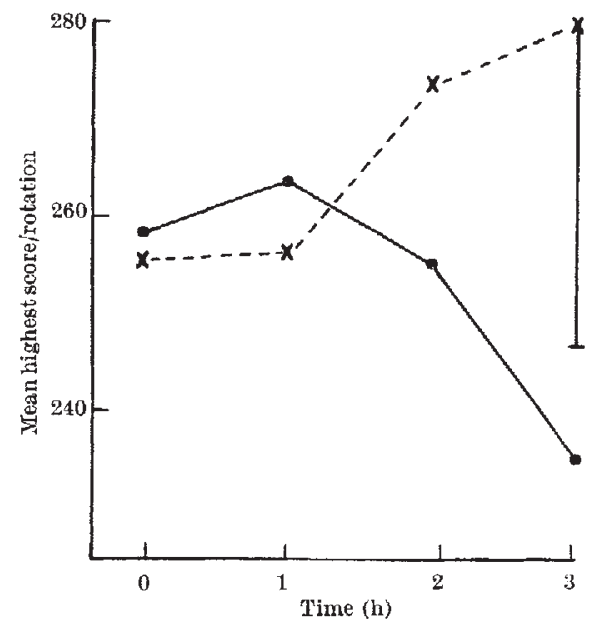

Fig. 1. Changes in mean highest score/rotation at $0,1,2$ and $3 \mathrm{~h}$ after administration of promethazine hydrochloride $(50 \mathrm{mg})(-\mathrm{and}$ vlacebo $(-.$.$) in four subjects. The 95$ per cent confidence limits (l-tail test) were shown for placebo at $3 \mathrm{~h}$

The present results demonstrate that promethazine hydrochlorido significantly impairs hand-oye co-ordination. The dose used was sufficient to produce subjective symptoms of central depression in all the subjects, and furthor oxperiments are planned to investigate more fully the effoct of smaller doses of this and other antihistamine drugs. This is of importance in view of the ease with which these drugs can be obtained by the general public, and of the possible hazards involved in driving and other complex tasks.

The apparatus used in this experiment was easy to construct and the subjects readily became proficient in its use.

We thank Prof. W. P. Colquhoun, Prof. M. Weatherall, Prof. E. F. Scowen, Dr. A. H. Goodspeed and the staff of Northampton College for their advice. Mossrs. E. Langcaster and E. Caswell assisted in the design and construction of the apparatus, and students of Northampton College co-operated as subjects for the experiments. May and Baker, Ltd., provided tablets of promethazine and placobo. One of us (P. T.) is in receipt of a Welleome senior research fellowship in clinical science.

G. R. Molson

J. A. MaCkeY

Department of Ophthalmic Optics, Northampton College, London, E.C.1.

\section{J. V. SMarT}

Departmont of Statisties, Research and Development, Smith, Kline and French Laboratories, Ltd. Welwyn Garden City, Herts.

Paul Turner

Medical Professorial Unit,

St. Bartholomew's Hospital, London, E.C.1.

${ }^{1}$ Norman, T. G., Pharmaceutical $J_{\text {, }} 189$ (February 29, 1964).

${ }^{2}$ Ruback, G. S., Krasno, L. R., and Ivy, A. C., J. App. Physiol., 4, 560 (1952).

${ }^{3}$ Payne, R. R., Some Psychological Factors Governing the Impairment of Verbal Retention by Cerebral Depressants, U.S. Air Force Sch. Av. Med. Rep. No. 55-52 (1955).

- Colquhoun, W. P., Brit. J. Indust. Med., 19, 287 (1962). 